\title{
Rumah Kreatif dan Inovasi Sebagai Program Pemberdayaan Masyarakat Kampung Muara Bahari
}

\author{
Anita Yunia ${ }^{1}$, Janette Maria Pinariya ${ }^{2}$ \\ Sekolah Tinggi Ilmu Komunikasi LSPR Jakarta, Indonesia
}

\begin{abstract}
ABSTRAK
Banyaknya jumlah penyalahgunaan dan peredaran narkoba di Indonesia, membuat semakin banyak upaya-upaya pencegahan dan pemberantasan narkoba dari berbagai pihak, salah satunya adalah pihak pemerintah Badan Narkotika Nasional (BNN). Selain menjalani tugas pokok dalam program Pencegahan Pemberantasan Penyalahgunaan dan Peredaran Gelap Narkoba (P4GN), BNN juga menerapkan program pemberdayaan alternatif sebagai program pendukung untuk mewujudkan Indonesia bebas narkoba. Kampung Muara Bahari merupakan salah satu wilayah sasaran program pemberdayaan alternatif yang dilakukan BNN Kota Jakarta Utara bersama PT Indonesia Power UPJP Priok. Pemberdayaan alternatif ini dilakukan berdasarkan banyaknya pengguna narkoba yang direhabilitasi serta temuan kasus narkoba di wilayah tersebut. Upaya pemberdayaan di kampung Muara Bahari ini dilakukan di Rumah Kreatif dan Inovasi dengan menghadirkan berbagai program kreatif dan inovasi melalui metodologi sosialisasi, pelatihan dan pendampingan. Selain untuk meminimalisir angka pengguna narkoba, tujuan pemberdayaan ini dilakukan untuk meningkatkan keterampilan dan kreativitas masyarakat dan klien pascarehabilitasi narkoba. Berdasarkan hasil evaluasi, upaya pemberdayaan yang dilakukan di Rumah Kreatif dan Inovasi ini membawa banyak perubahan kepada masyarakat. Selain dapat meningkatkan keterampilan dan pendapatan ekonomi masyarakat, pemberdayaan ini membuat tali silaturahmi masyarakat kampung Muara Bahari menjadi saling terjaga.
\end{abstract}

Kata Kunci: Indonesia Darurat Narkoba, Partisipasi Masyarakat, Pemberdayaan Alternatif, Pencegahan dan Pemberantasan

\section{ABSTRACT}

The large number of drug abuse and distribution in Indonesia, makes more efforts to prevent and eradicate drugs from various parties, one of them is the government of the National Narcotics Agency. In addition to undergoing the main tasks in the Prevention of the Eradication of Drug Abuse and Circulation Narcotics, National Narcotics Agency also implements an alternative empowerment program as a support program to realize a drug-free Indonesia. Muara Bahari village is one of the target areas for alternative empowerment programs conducted by the North Jakarta National Narcotics Agency with PT Indonesia Power UPJP Priok. This alternative empowerment is based on the number of drug users being rehabilitated as well as drug case findings in the region. The empowerment effort in Muara Bahari village was carried out at the Rumah Kreatif and Inovasi by presenting various creative and innovation programs through socialization, training and mentoring methodologies. In addition to minimizing the number of drug users, the purpose of this empowerment is to increase the skills and creativity of the community and drug rehabilitation clients. Based on the results of the evaluation, the empowerment efforts undertaken at the Rumah Kreatif and Inovasi brought many

CONTACT Anita Yunia. Sekolah Tinggi Ilmu Komunikasi LSPR, Jakarta, Indonesia. Sudirman Park Campus, Jl. Jend. Sudirman No.Kav. 32, RT.12/RW.11, Karet Tengsin, Kota Jakarta Pusat, Daerah Khusus Ibukota Jakarta 10250. Email: anitayunia32@gmail.com 
changes to the community. In addition to being able to improve the skills and economic income of the community, this empowerment has made the community ties in Muara Bahari village maintained by one another.

Keywords: Indonesia Drug Emergency, Community Participation, Alternative Empowerment, Prevention and Eradication

\section{PENDAHULUAN}

Indonesia merupakan negara kepulauan terbesar di dunia dan menjadi negara dengan penduduk terbesar di kawasan Asia Tenggara. Kondisi Indonesia menjadi kian kompleks dengan munculnya berbagai macam masalah sosial. Salah satu masalah serius yang sering terjadi di Indonesia adalah masalah narkoba. Pada tahun 2015, Presiden Republik Indonesia Joko Widodo membuat pernyataan "Indonesia Darurat Narkoba" (Media Keuangan, 2018). Pernyataan ini disampaikan setelah presiden menelaah hasil survei dalam laporan kinerja Badan Narkotika Nasional (BNN) pada tahun 2015 dan ditandai dengan banyaknya jumlah pengguna narkoba yang direhabilitasi (Damanik, 2015).

Merujuk data BNN, angka prevalensi penyalahgunaan narkotika di Indonesia pada tahun 2018 mencapai angka 3,2 persen atau setara dengan 2,29 juta orang. Sementara pada tahun 2017, angka prevalensi penyalahgunaan narkotika sebesar 1,77 persen atau setara 3.37 juta orang (Ristianti, 2019).

Terkait jumlah penyalahgunaan dan peredaran narkoba yang semakin meningkat, membuat semakin banyak upaya pencegahan dan pemberantasan narkoba yang dilakukan Badan Narkotika Nasional (BNN). Selain menjalani tugas pokok dalam program Pencegahan dan Pemberantasan Penyalahgunaan dan Peredaran Gelap Narkotika (P4GN), BNN juga menerapkan program pemberdayaan alternatif sebagai program pendukung untuk mewujudkan Indonesia bebas narkoba (Nopitasari \& Rostyaningsih, 2017).

Pada jurnal sebelumnya, pemberdayaan alternatif dilakukan BNN Kota Jakarta Timur di kampung Pertanian sejak tahun 2013. Upaya pemberdayaan ini dilakukan dengan menghadirkan pelatihan keterampilan tata boga, pelatihan peningkatan kemampuan wirausaha, tata rias pengantin, kerajinan daur ulang, handy craft, servis handphone dan pelatihan perbengkelan. Pemberdayaan alternatif ini dilakukan selama tiga tahun. Namun hasil pemberdayaan menunjukkan bahwa upaya pencegahan dan pemberantasan narkoba di kampung Pertanian belum dapat teratasi dengan baik dikarenakan kasus penyalahgunaan dan peredaran narkoba masih sering terjadi di wilayah tersebut (Nopitasari \& Rostyaningsih, 2017). 
Penetapan wilayah sasaran program pemberdayaan alternatif selanjutnya juga dilakukan BNN Kota Jakarta Utara di kampung Muara Bahari. Upaya pemberdayaan ini dilakukan berdasarkan banyaknya pengguna narkoba yang direhabilitasi serta temuan kasus narkoba di wilayah tersebut. Sepanjang tahun 2017, BNN Kota Jakarta Utara berhasil menangkap 102 pengguna narkoba dan 12 diantaranya adalah pengedar. Pada tahun selanjutnya, BNN Kota Jakarta Utara mengungkap 12 kasus serta melakukan tindakan rehabilitasi kepada 166 pengguna narkoba (Hamonangan, 2018a).

Pada tanggal 24 Agustus 2018, BNN Kota Jakarta Utara, Pemerintah Daerah Jakarta Utara bersama PT Indonesia Power UPJP Priok serta pemangku kepentingan lainnya meresmikan Rumah Kreatif dan Inovasi sebagai wadah pemberdayaan masyarakat di kampung Muara Bahari. Kepala BNN Kota Jakarta Utara, Yuanita Kamelia Sari (dalam Hamonangan, 2018b) menyatakan bahwa Rumah Kreatif dan Inovasi ini merupakan pengembangan posko Pencegahan dan Pemberantasan Penyalahgunaan dan Peredaran Gelap Narkotika (P4GN) BNN Kota Jakarta Utara, namun dengan adanya kerjasama dari berbagai pemangku kepentingan, posko ini berkembang menjadi wadah pelayanan narkoba yang memenuhi standar untuk mengembalikan fungsi sosial penyalahgunaan narkoba di kampung Muara Bahari.

Upaya pemberdayaan yang dilakukan di Rumah Kreatif dan Inovasi ini dilakukan dengan menghadirkan berbagai program kreatif dan inovasi diantara lain adalah program kreativitas, program soft skills dan program belajar mengajar. Selain untuk meminimalisir jumlah pengguna narkotika di kampung Muara Bahari, tujuan program pemberdayaan ini dilakukan untuk meningkatkan keterampilan dan kreativitas masyarakat, khususnya anak-anak muda yang rentan dalam masalah narkoba serta klien pascarehabilitasi narkoba BNN Kota Jakarta Utara. Tujuan pemberdayaan lainnya juga dituangkan dalam Undang-undang Nomor 6 Tahun 2014 tentang Desa pasal 1 ayat 12 yang menjelaskan bahwa pemberdayaan masyarakat desa adalah upaya mengembangkan kemandirian dan kesejahteraan masyarakat dengan meningkatkan pengetahuan, sikap, keterampilan, perilaku, kemampuan, kesadaran, serta memanfaatkan sumber daya melalui penetapan kebijakan, program, kegiatan dan pendampingan yang sesuai dengan esensi masalah dan prioritas kebutuhan masyarakat desa.

Upaya mengembangkan kemandirian dan kesejahteraan masyarakat dalam pemberdayaan tidak lepas dari kontribusi dan partisipasi masyarakat, mulai dari proses perencanaan, pelaksanaan, hingga tahap evaluasi. Economic Commission for Latin American (1982) mendefinisikan partisipasi "as a voluntary contribution by the people in one or another of the public programmes supposed to contribute to national development" (Nikkah \& Redzuan, 2009). Sementara Menurut Isbandi (2007, dalam Hajar, 2018) partisipasi adalah "keikutsertaan masyarakat dalam proses pengidentifikasian masalah dan potensi yang ada di masyarakat, pemilihan dan pengambilan keputusan tentang alternatif dan solusi untuk 
menangani masalah, dan keterlibatan masyarakat dalam proses mengevaluasi perubahan yang terjadi" (p.30).

Hal yang diharapkan adanya partisipasi dalam program pemberdayaan masyarakat adalah meningkatnya kemampuan setiap orang yang terlibat dalam pemberdayaan masyarakat, baik secara langsung maupun tidak langsung.

Pemberdayaan selalu berkaitan dengan rencana pembangunan masyarakat dan dihubungkan dengan konsep mandiri, partisipasi, jaringan kerja dan keadilan. Istilah pemberdayaan lahir sebagai antithesis terhadap model pembangunan dan model industrialisasi yang kurang memihak pada rakyat mayoritas. Arsiyah et al. (2009, dalam Hajar, 2018) menyatakan bahwa "konsep pemberdayaan merupakan paradigma baru dalam pembangunan masyarakat yang melibatkan masyarakat dalam kegiatan pembangunan baik dalam perencanaan, pelaksanaan maupun evaluasi" (p.46). Adams (1990 dalam Jack, 1995) mendefinisikan bahwa pemberdayaan sebagai berikut:

"Empowerment has been described as the process by which individuals, groups and/or communities become able to take control of their circumstances and achieve their own goals, thereby being able to work towards maximising the quality of their lives" Adams (1990, dalam Jack, 1995).

Selain itu, Maton (2008, dalam Christens, 2012) juga mendefinisikan pemberdayaan:

"a group-based, participatory, developmental process through which marginalized or oppressed individuals and groups gain greater control over their lives and environment, acquire valued resources and basic rights, and achieve important life goals and reduced societal mar-ginalization" (p.542).

Pemberdayaan masyarakat merupakan suatu proses pengembangan potensi dan kemampuan untuk memecahkan masalah-masalah yang dihadapi masyarakat. Kegiatan pemberdayaan masyarakat dalam pelaksanaannya membutuhkan kerja sama yang baik antar semua pihak, dimana anggota masyarakat menjadi pemeran utama untuk mengembangkan potensi yang dimiliki sehingga dapat dimanfaatkan secara maksimal. Keterlibatan masyarakat dalam kegiatan pemberdayaan masyarakat ini dimulai dari proses perencanaan, pelaksaan, hingga tahap evaluasi.

Undang-undang Nomor 6 Tahun 2014 tentang Desa pasal 1 ayat 12 menjelaskan bahwa pemberdayaan masyarakat desa adalah upaya mengembangkan kemandirian dan kesejahteraan masyarakat dengan meningkatkan pengetahuan, sikap, keterampilan, perilaku, kemampuan, kesadaran, serta memanfaatkan sumber daya melalui penetapan kebijakan, program, kegiatan dan pendampingan yang sesuai dengan esensi masalah dan prioritas kebutuhan masyarakat desa. Upaya pemberdayaan masyarakat perlu didasari pemahaman 
bahwa munculnya ketidak berdayaan masyarakat muncul karena masyarakat tidak memiliki kekuatan (powerless).

Hal yang diharapkan adanya partisipasi dalam program pemberdayaan masyarakat adalah meningkatnya kemampuan setiap orang yang terlibat dalam pemberdayaan masyarakat, baik secara langsung maupun tidak langsung. Isbandi (2007, dalam Hajar, 2018) menyatakan bahwa partisipasi adalah "keikutsertaan masyarakat dalam proses pengidentifikasian masalah dan potensi yang ada di masyarakat, pemilihan dan pengambilan keputusan tentang alternatif dan solusi untuk menangani masalah, dan keterlibatan masyarakat dalam proses mengevaluasi perubahan yang terjadi" (p.30). Menurut Conyers (dalam Hajar 2012, dalam Hajar, 2018) pentingnya partisipasi dalam pemberdayaan masyarakat ini adalah:

"partisipasi merupakan suatu alat guna memperoleh informasi mengenai kondisi, kebutuhan, dan sikap masyarakat setempat, yang tanpa kehadirannya program pembangunan serta proyek-proyek akan gagal. Masyarakat akan lebih mempercayai proyek atau program pembangunan jika merasa dilibatkan dalam proses persiapan dan perencanaannya, karena mereka akan lebih mengetahui seluk-beluk proyek tersebut dan akan mempunyai rasa memiliki terhadap proyek-proyek tersebut" (p.32).

Dusseldorp (1981, dalam Hajar, 2018, p.34) mengidentifikasi ragam bentuk kegiatan partisipasi yang dilakukan masyarakat: (1) Menjadi anggota kelompok-kelompok masyarakat, (2) Melibatkan diri pada kegiatan diskusi kelompok, (3) Melibatkan diri pada kegiatankegiatan organisasi untuk menggerakkan partisipasi masyarakat yang lain, (4) Menggerakkan sumber daya masyarakat, (5) Mengambil bagian dalam proses pengambilan keputusan, (6) Memanfaatkan hasil-hasil yang dicapai dari kegiatan masyarakatnya.

Menurut (Situmeang, 2016) ada beberapa pihak yang terlibat dalam pemberdayaan masyarakat, yaitu: (1) Pemerintah : Pemerintah merupakan pihak yang paling bertanggung jawab dalam upaya menyejahterakan masyarakatnya sehingga memiliki porsi yang paling besar dalam pengembangan masyarakat, pemegang kekuasaan yang dimandatkan oleh warganya, serta membuat regulasi yang ditujukan kepada terciptanya kehidupan masyarakat yang sejahtera. (2) Organisasi. Organisasi yang terlibat dalam pemberdayaan masyarakat merupakan organisasi yang ikut berkontribusi melaksanakan program pemberdayaan. Organisasi ini turut menyediakan dana dan merencanakan kegiatan pengembangan masyarakat. (3) Masyarakat. Masyarakat tidak hanya dipandang sebagai obyek kegiatan yang menerima hasil kegiatan pengembangan masyarakat, melainkan sebagai pihak yang ikut berkontribusi dalam merencanakan program pemberdayaan. Tidak hanya itu, masyarakat juga dituntut untuk aktif dan bertanggung jawab dalam pengambilan keputusan bersama. (4) Pelaksana/Agen Perubahan. Pelaksana/agen perubahan pada umunya memiliki kesadaran dan kepedulian yang cukup tinggi terhadap pengembangan masyarakat atau yang biasa disebut community organizer atau $C D$ worker. 


\section{METODOLOGI PELAKSANAAN}

Metode atau bentuk kegiatan dalam program pemberdayaan masyarakat yang dilakukan di Rumah Kreatif dan Inovasi adalah:

\section{Sosialisasi}

Pelaksanaan kegiatan diawali dengan melakukan pendekatan kepada masyarakat, klien pascarehabilitasi narkoba BNN Kota Jakarta Utara, serta para pemangku kepentingan terkait. Pendekatan ini diarahkan melalui proses sosialisasi tentang pentingnya keberadaan Rumah Kreatif dan Inovasi sebagai wadah pelayanan narkoba yang memenuhi standar untuk mengembalikan fungsi sosial penyalahgunaan narkoba di kampung Muara Bahari. Kegiatan sosialisasi ini rutin dilakukan tiap bulannya, baik dalam bentuk rapat, Focus Group Discussion (FGD) maupun acara-acara lainnya. Selain untuk meningkatkan motivasi masyarakat, tujuan kegiatan sosialisasi ini adalah untuk mengetahui perkembangan program pemberdayaan yang dilakukan di Rumah Kreatif dan Inovasi. Dalam kegiatan sosialisasi ini, masyarakat, klien pascarehabilitasi narkoba serta pemangku kepentingan terkait saling menyampaikan aspirasi dan pendapatnya untuk dijadikan sebagai bahan evaluasi program pemberdayaan selanjutnya.

\section{Pelatihan dan Pendampingan}

Pelatihan dan pendampingan dalam pemberdayaan masyarakat di Rumah Kreatif dan Inovasi ini dilakukan pada tiga jenis program, yaitu: (a) Program Kreativitas. Pelatihan dan pendampingan yang diberikan dalam program kreativitas ini dilakukan dari awal kegiatan pengadaan bahan-bahan dan peralatan, proses pembuatan produk, desain kemasan dan sistem manajemen pemasaran produk. (b) Program Soft Skills. Pelatihan dan pendampingan yang diberikan dalam program soft skills ini berupa penyampaian materi, kegiatan praktek, dan diskusi. (c) Program Belajar dan Mengajar. Pelatihan dan pendampingan yang diberikan dalam program belajar dan mengajar ini berupa penyampaian materi, pembuatan soal, diskusi tanya jawab dan kompetisi.

Tujuan adanya pelatihan dan pendampingan dalam program pemberdayaan masyarakat ini adalah meningkatnya kemampuan dan keterampilan masyarakat dalam setiap program yang dijalani. Dengan adanya pelatihan dan pendampingan, kegiatan dalam program pemberdayaan masyarakat akan menjadi lebih terarah dan terstruktur, sehingga masyarakat dan klien pascarehabilitasi narkoba mampu memahami setiap rangkain kegiatan program dengan baik. Kegiatan pelatihan dan pendampingan ini dilakukan selama lima tahun, di mulai dari tahap perencanaan hingga evaluasi. Setelah menjalani pelatihan dan pendampingan, seluruh masyarakat dan klien pascarehabilitasi narkoba diharapkan dapat mengembangkan kemampuan dan keterampilannya secara mandiri. Sosmap pelatihan dan pendampingan program pemberdayaan masyarakat di Rumah Kreatif dan Inovasi selama lima tahun adalah sebagai berikut. 2018: Peningkatan sarana dan prasarana, 2019: Peningkatan kapasitas, 
2020: Perluasan sistem manajemen pemasaran, 2021: Pengembangan inkubasi bisnis, 2022: Pemandirian Rumah Kreatif dan Inovasi.

\section{HASIL DAN PEMBAHASAN}

\section{Pelatihan dan Pendampingan Program Kreativitas}

Kegiatan pelatihan dan pendampingan daur ulang dan handycraft ini dibantu oleh salah satu lembaga sosial, yaitu yayasan Kumala (Kreasi Usaha Mandiri Alami). Yayasan Kumala ini merupakan binaan PT Pertamina Hulu Energi Offshore North West Java yang berdiri sejak tahun 2006 fokus dalam pembinaan dan pemberdayaan anak-anak jalanan di wilayah Jakarta Utara. Anak-anak jalanan diberikan pelatihan pengelolaan sampah non-B3 menjadi produkproduk kreatif yang mempunyai nilai ekonomi tinggi. Produk-produk daur ulang yang dihasilkan antara lain adalah tempat tissue, bingkai foto, kertas undangan dan lain-lain (Prakoso, 2017).

BNN Kota Jakarta Utara bersama PT Indonesia Power UPJP Priok serta pemangku kepentingan lainnya memberi kepercayaan kepada yayasan Kumala sebagai role model yang efektif dalam program pemberdayaan untuk serta memberikan pelatihan dan pendampingan daur ulang dan handycraft kepada masyarakat kampung Muara Bahari dan klien pascarehabilitasi narkoba di Rumah Kreatif dan Inovasi. Tujuan pelatihan dan pendampingan daur ulang dan handycraft ini agar anak-anak muda maupun ibu-ibu rumah tangga memiliki kegiatan positif yang dapat meningkatkan keahlian dan keterampilan dalam pembuatan produk kreatif dan inovasi yang memiliki nilai ekonomi yang tinggi.

\section{Gambar 1. Produk kreatif dan inovasi masyarakat dan klien pascarehabilitasi narkoba}

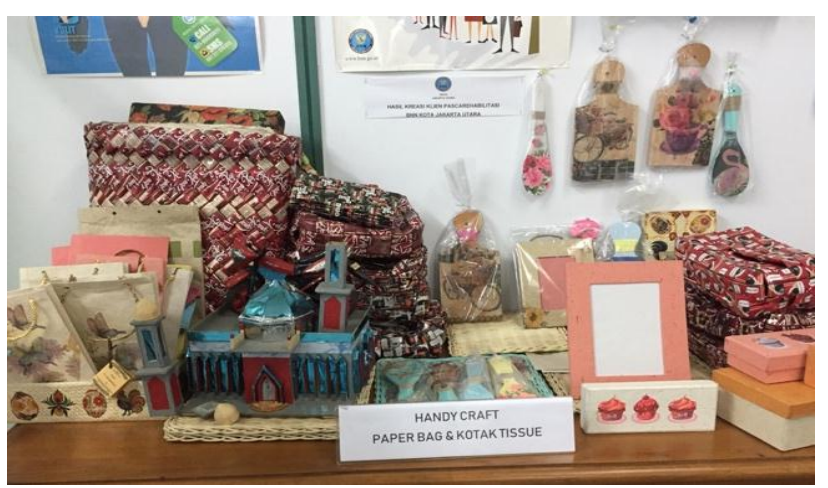

Sumber: Data Primer (2019)

Pelatihan dan pendampingan ini dilakukan dua kali setiap bulannya. Bahan-bahan yang digunakan untuk membuat produk kreativitas ini merupakan bahan-bahan alami ramah lingkungan. Produk-produk yang dihasilkan masyarakat dan klien pascarehabilitasi selama hampir satu tahun menjalani pelatihan dan pendampingan daur ulang dan handycraft antara lain adalah bingkai foto, seni dekopas, paper bag, pouch, kotak tissue dan anyaman. 
Berkat kerjasama dan kerja keras masyarakat, produk-produk kreatif dan inovasi ini mendapat banyak perhatian dari berbagai instansi maupun Kementerian Lingkungan Hidup dan Kehutanan. Selain menggunakan bahan yang ramah lingkungan, produk ini memiliki detail yang sangat menarik.

Selain pembuatan produk, sistem manajemen pemasaran juga perlu diperhatikan agar produk yang dihasilkan dapat terdistribusi dengan baik. Berkat kemajuan dan perkembangan teknologi, produk-produk masyarakat ini rencana nya akan dipasarkan secara online melalui platform media sosial seperti Instagram, Facebook dan lain-lain. Berdasarkan hasil studi Polling Indonesia bersama Asosiasi Penyelenggara Jasa Internet Indonesia (APJII) jumlah pengguna internet di Indonesia meningkat 10,12\%. Sekjen APJII, Henri Kasyfi menyatakan bahwa 64,8\% dari total penduduk Indonesia telah terhubung ke internet (Pratomo, 2019). Dari hasil pengguna internet di Indonesia, Wearesosial Hootsuite menyatakan bahwa 56\% penduduk Indonesia menggunakan internet untuk mengakses media sosial (We Are Sosial, 2019). Banyaknya jumlah penduduk, serta pertumbuhan pengguna internet dan media sosial di Indonesia menjadi peluang besar bagi masyarakat kampung Muara Bahari dan klien pascarehabilitasi narkoba untuk memasarkan produknya tanpa batas ruang dan waktu.

\section{Pelatihan dan Pendampingan Program Soft Skills}

Selain program kreativitas, masyarakat dan klien pascarehabilitasi narkoba BNN Kota Jakarta Utara juga diberikan pelatihan dan pendampingan program soft skills. Dimana soft skills merupakan kemampuan interpersonal yang mengacu pada karakteristik bagaimana manusia bersikap, berinteraksi, dan berkomunikasi dengan orang lain. Program soft skills yang diberikan dalam pemberdayaan ini antara lain adalah public speaking, leadership dan administrasi. Tujuan adanya program soft skills ini adalah meningkatkan kemampuan masyarakat dalam berkomunikasi.

\section{Gambar 2. Pelatihan dan pendampingan kegiatan leadership}

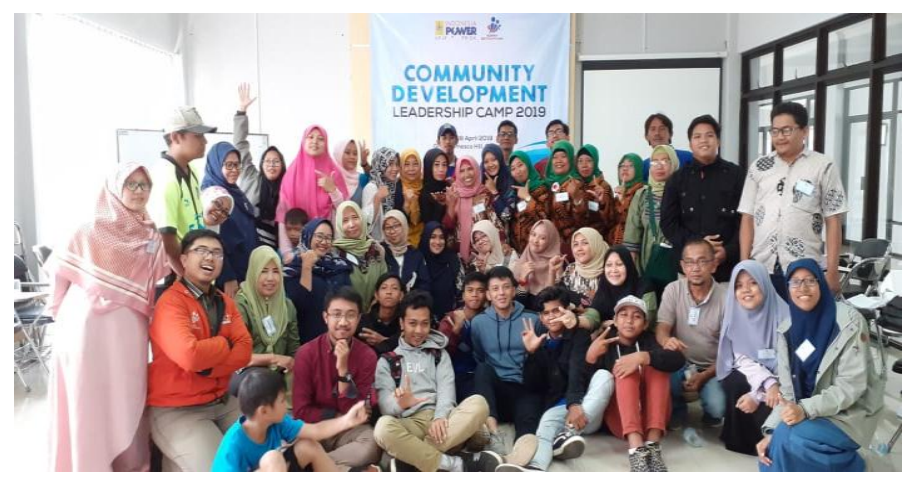

Sumber: Data Primer (2019)

Berdasarkan hasil wawancara yang dilakukan pada klien pascarehabilitasi, program soft skills ini sangat membantu klien pascarehabilitasi untuk mengembalikan rasa percaya dirinya ketika 
berhadapan dengan lingkungan. Klien pascarehabilitasi menyatakan bahwa masih banyak masyarakat yang berpandangan negatif terhadap mantan pengguna narkoba. Hal ini membuat sebagian klien pascarehabilitasi takut dan kurang percaya diri untuk kembali ke lingkungannya. Maka dari itu, BNN Kota Jakarta Utara dan pemangku kepentingan lainnya berupaya memberikan pelatihan dan pendampingan soft skills untuk menghindari adanya gap komunikasi antar klien pascarehabilitasi narkoba dan masyarakat. Selain memiliki kemampuan berkomunikasi, para pemangku kepentingan berharap bahwa masyarakat dan klien pascarehabilitasi mempunyai jiwa kepemimpinan yang tinggi dan bertanggung jawab.

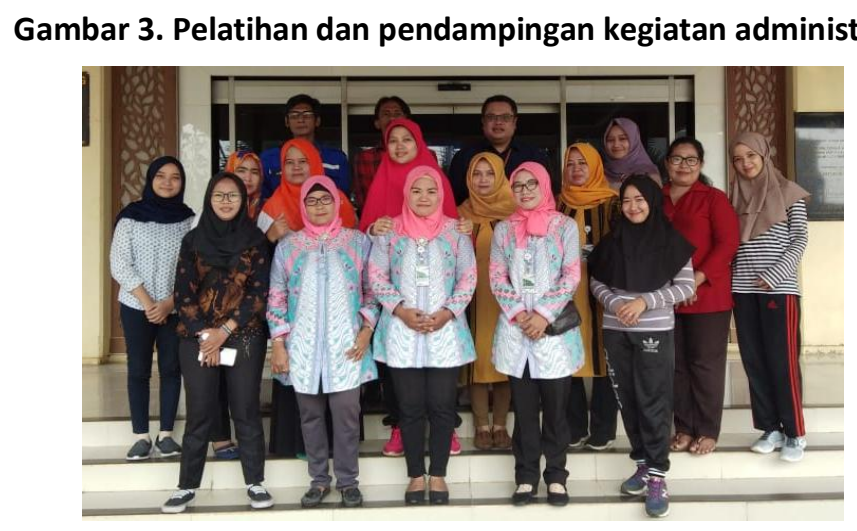

Sumber: Data Primer (2019)

\section{Pelatihan dan Pendampingan Program Belajar dan Mengajar}

Pelatihan dan pendampingan program belajar dan mengajar di Rumah Kreatif dan Inovasi ini merupakan inisiatif partisipasi dari masyarakat. Hal yang diharapkan adanya partisipasi dalam upaya pemberdayaan masyarakat adalah meningkatnya kemampuan setiap orang yang terlibat dalam pemberdayaan masyarakat, baik secara langsung maupun tidak langsung. Isbandi (2007, dalam Hajar, 2018) juga menyatakan bahwa partisipasi adalah "keikutsertaan masyarakat dalam proses pengidentifikasian masalah dan potensi yang ada di masyarakat, pemilihan dan pengambilan keputusan tentang alternatif dan solusi untuk menangani masalah, dan keterlibatan masyarakat dalam proses mengevaluasi perubahan yang terjadi" (p.30).

Program belajar mengajar ini dilakukan atas dasar permasalahan pendidikan anak-anak yang belum merata. Dengan adanya program belajar mengajar ini, anak-anak yang belum atau tidak bersekolah bisa mendapat pengetahuan baru, sedangkan bagi anak-anak yang sedang menjalani pendidikan dapat memperoleh pengetahuan dan wawasan yang lebih luas.

Program belajar mengajar ini dilakukan kepada anak-anak dari kelas satu sampai kelas enam Sekolah Dasar (SD). Materi yang diberikan dalam program belajar mengajar ini disesuaikan dengan kurikulum sekolah dan dilakukan pada setiap hari senin dan kamis pada pukul 15.3017.00 WIB. Namun yang membedakan metode belajar mengajar di sekolah dan di Rumah Kreatif dan Inovasi ini adalah penyesuaian antara minat dan kebutuhan anak-anak. Misalnya 
anak A dan B gemar belajar matematika, maka pengajar akan memberikan materi hitung menghitung. Sedangkan jika anak $X$ dan $Y$ gamar pelajaran Ilmu Pengetahuan Alam (IPA), maka pengajar akan memberikan pelajaran seputar Ilmu Pengetahuan Alam.

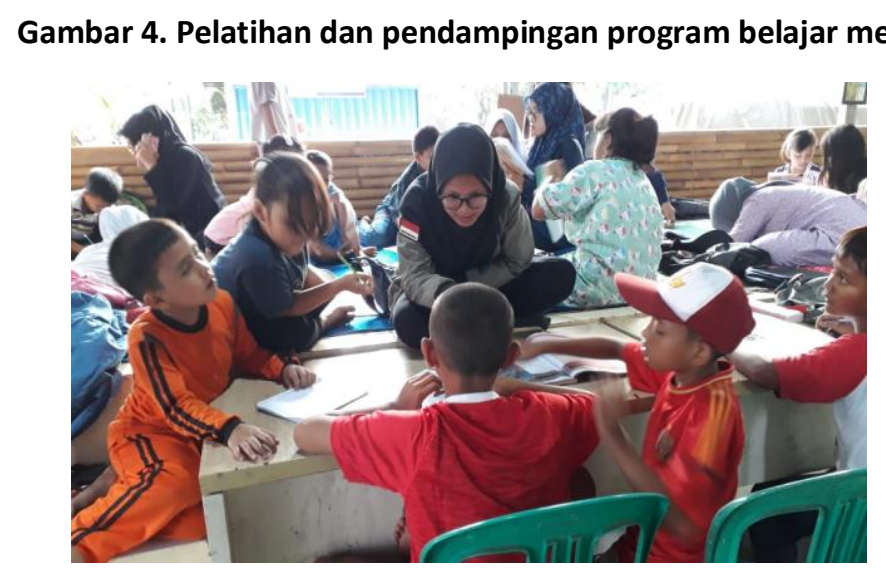

Sumber: Data Primer (2019)

Untuk mendukung kegiatan belajar mengajar di Rumah Kreatif dan Inovasi, BNN Kota Jakarta Utara dan para pemangku kepentingan terkait juga menyediakan fasilitas Taman Bacaan Mini yang dilengkapi dengan buku-buku bacaan yang menarik dan bermanfaat. Taman Bacaan Mini ini dapat dimanfaatkan oleh semua lapisan masyarakat di kampung Muara Bahari.

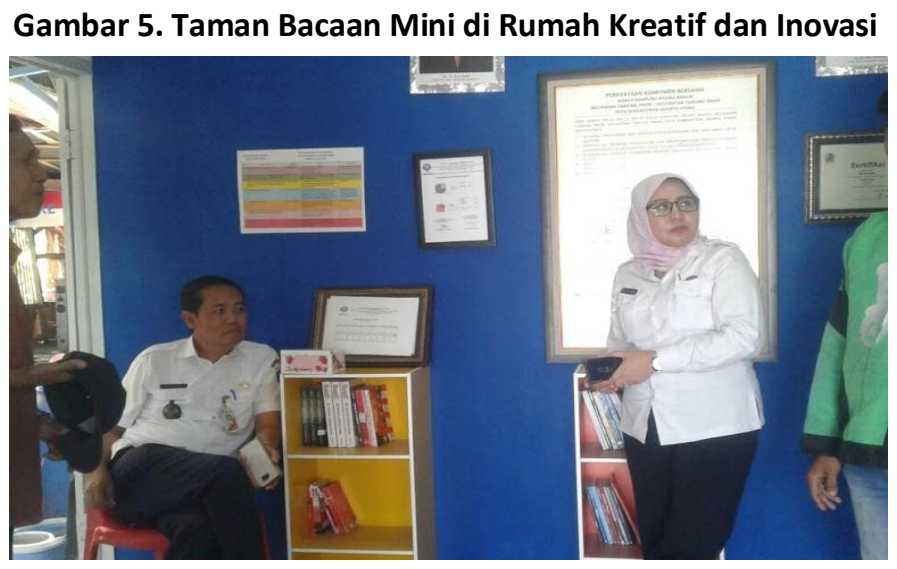

Sumber: Data Primer (2019)

\section{Kegiatan Masyarakat}

Selain menjadi wadah program pemberdayaan masyarakat, Rumah Kreatif dan Inovasi ini juga digunakan sebagai wadah kegiatan masyarakat. Tujuan Rumah Kreatif dan Inovasi sebagai wadah kegiatan masyarakat ini adalah untuk memperkuat tali silaturahmi masyarakat kampung Muara Bahari. Kegiatan-kegiatan yang biasa dilakukan masyarakat di Rumah Kreatif dan Inovasi ini diantara lain adalah pengajian malam, latihan marawis, rapat, buka puasa bersama, arisan dan lain-lain. Kegiatan pengajian malam dan latihan marawis ini biasa dilakukan ibu-ibu setelah menjalani ibadah shalat isya. 
Gambar 6. Kegiatan marawis di Rumah Kreatif dan Inovasi

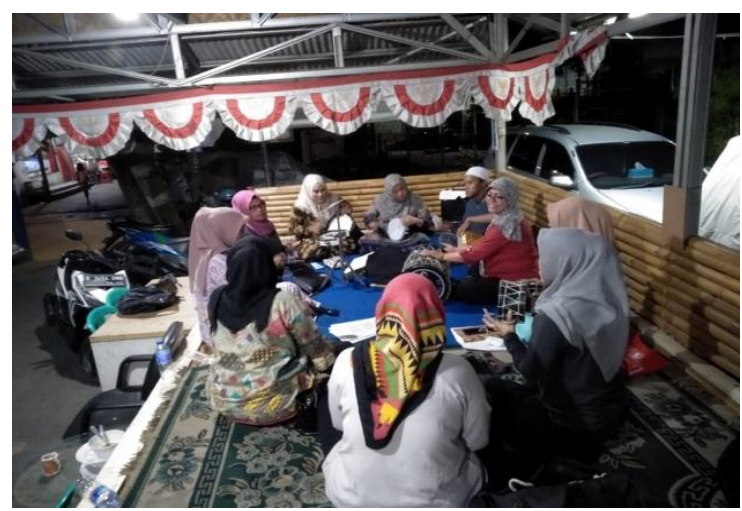

Sumber: Data Primer (2019)

Gambar 7. Kegiatan mengaji malam di Rumah Kreatif dan Inovasi

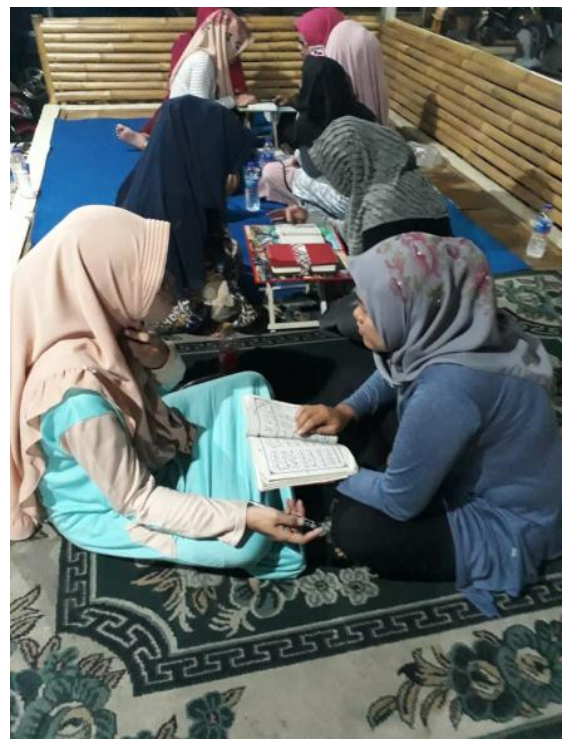

Sumber: Data Primer (2019)

\section{Evaluasi}

Kondisi mood yang tidak stabil merupakan salah satu penyebab minimnya partisipasi klien pascarehabilitasi narkoba dalam program pemberdayaan di Rumah Kreatif dan Inovasi. Selama satu tahun program berjalan, hanya tiga klien pascarehabilitasi narkoba yang benarbenar produktif mengikuti kegiatan program pemberdayaan.

Setelah beberapa bulan menjalani pelatihan dan pendampingan daur ulang dan handycraft ini, masyarakat dan klien pascarehabilitasi narkoba sudah mulai terampil dan mandiri. Meskipun jadwal pelatihan belum begitu efektif, masyarakat dan klien pascarehabilitasi narkoba memiliki semangat dan inisiatif yang tinggi untuk terus berlatih bersama di luar jadwal pelatihan.

Selama satu tahun program berjalan, masyarakat dan klien pascarehabilitasi berhasil memproduksi beberapa produk kreativitas, diantara lain paper bag, bingkai foto, kotak tissue, 
ecobricks, seni dekopas, pouch dan anyaman. Selain mendapat banyak perhatian dari berbagai instansi, produk-produk kreativitas juga diberi kesempatan tampil dalam pameran acara perayaan ulang tahun PT Indonesia Power UPJP Priok.

Produk-produk kreativitas ini dipasarkan ke beberapa instansi dan kelurahan. Sistem manajemen pemasaran lainnya akan ditingkatkan secara online melalui platform media sosial Instagram dan Facebook.

Kegiatan masyarakat yang dilakukan di Rumah Kreatif dan Inovasi semakin beragam. Selain digunakan sebagai wadah kegiatan sehari-hari, masyarakat juga memanfaatkan Rumah Kreatif dan Inovasi untuk acara-acara perayaan nasional.

Agar fungsi Rumah Kreatif dan Inovasi dapat digunakan secara maksimal, maka para pemangku kepentingan membuat sebuah forum komunikasi untuk mengomunikasikan Rumah Kreatif dan Inovasi. Hal ini dilakukan karena masih banyak sebagian masyarakat yang menganggap bahwa Rumah Kreatif dan Inovasi ini milik BNN Kota Jakarta Utara, sehingga masyarakat kurang aktif untuk mengikuti kegiatan di Rumah Kreatif dan Inovasi. Dengan adanya forum komunikasi ini, seluruh pemangku kepentingan berharap masyarakat tidak memiliki batasan untuk melakukan kegiatan positif.

Agar Rumah Kreatif dan Inovasi ini terlihat hidup dan ramai, maka BNN Kota Jakarta Utara bersama PT Indonesia Power UPJP Priok memiliki strategi untuk bekerja sama dengan NGO serta melakukan kampanye narkoba.

\section{Hambatan}

Hambatan yang terjadi dalam program pemberdayaan masyarakat di Rumah Kreatif dan Inovasi adalah sulitnya menentukan kegiatan yang sesuai dengan minat dan kebutuhan klien pascarehabilitasi narkoba. Kondisi mood yang naik turun (tidak stabil) menjadi penyebab minimnya komitmen dan partisipasi klien pascarehabilitasi dalam program pemberdayaan di Rumah Kreatif dan Inovasi. Berdasarkan hasil wawancara yang dilakukan kepada kasie rehabilitasi narkoba BNN Kota Jakarta Utara, klien pascarehabilitasi yang telah menjalani rangkaian kegiatan rehab lebih tertarik untuk langsung bekerja di luar dibandingkan mengikuti program pemberdayaan masyarakat. Dikarenakan sifat pemberdayaan masyarakat jangka panjang, tidak instan, namun tentunya masyarakat dan klien pascarehabilitasi narkoba dapat merasakan manfaat dari program pemberdayaan ini.

\section{SIMPULAN}

Upaya pemberdayaan masyarakat di kampung Muara Bahari ini memberikan banyak manfaat kepada masyarakat maupun klien pascarehabilitasi narkoba. Dengan adanya Rumah Kreatif 
dan Inovasi ini, tali silaturahmi antar masyarakat menjadi saling terjaga, kegiatan-kegiatan positif ini juga membuat masyarakat dan klien pascarehabilitasi menjadi produktif.

Pelaksanaan pemberdayaan masyarakat di Rumah Kreatif dan Inovasi ini tidak akan ada artinya apabila tidak ada partisipasi dari masyarakat. Keterlibatan masyarakat ini menjadi solusi dalam mengidentifikasi masalah serta pemilihan dan pengambilan keputusan untuk menangani masalah yang terjadi pada masyarakat di kampung Muara Bahari.

Berkat semangat dan antusias masyarakat, Rumah Kreatif dan Inovasi menjadi lebih hidup dan berwarna. Kini banyak masyarakat yang memanfaatkan Rumah Kreatif dan Inovasi tidak hanya sebagai wadah pemberdayaan saja, melainkan dijadikan sebagai wadah kegiatan masyarakat. Hal ini membuat fungsi Rumah Kreatif dan Inovasi menjadi lebih berkembang.

\section{UCAPAN TERIMA KASIH}

Ucapan terima kasih kami ucapkan kepada tim Humas dan Keamanan PT Indonesia Power UPJP Priok, Kasie Rehabilitasi Narkoba BNN Kota Jakarta Utara, Klien pascarehabilitasi narkoba BNN Kota Jakarta Utara dan masyarakat kampung Muara Bahari yang telah memberi bantuan dan dukungan dalam melaksanakan penelitian kegiatan pemberdayaan masyarakat di Rumah Kreatif dan Inovasi. 


\section{DAFTAR PUSTAKA}

Christens, B.D. (2012). Targeting Empowerment In Community Development: A Community Psychology Approach To Enhancing Local Power And Well-Being. Community Development Journal Vol 47 no 4. Diperoleh 10 Agustus dari http://citeseerx.ist.psu.edu/viewdoc/download?doi=10.1.1.985.550\&rep=rep1\&type= pdf

Damanik, C., (2015, Januari 20). Jokowi: Indonesia Darurat Narkoba. Diperoleh 10 Agustus 2019 dari

“https://regional.kompas.com/read/2015/01/20/19405801/Jokowi.Indonesia.Darurat. Narkoba"

Hajar, S., Tanjung, I.S., Tanjung, Y., Zulfahmi. (2018). Pemberdayaan dan Partisipasi Masyarakat Pesisir. Medan, Indonesia: Lembaga Penelitian dan Penulisan IImiah Aqli

Hamonangan, J. (2018a, Desember 31). BNNK Jakarta Utara Rehab 166 Pecandu Narkoba $\begin{array}{lllll}\text { Sepanjang } & \text { tahun } 2018 . & \text { Diperoleh } 10 & \text { Agustus }\end{array}$ darihttps://wartakota.tribunnews.com/2018/12/31/bnnk-jakarta-utara-rehab-166pecandu-narkoba-sepanjang-tahun-2018

Hamonangan, J. (2018b, Agustus 24). Rumah Kreatif di Tanjung Priok Jadi Sarana Mantan Pengguna Narkoba. Diperoleh 10 Agustus 2019 dari http://wartakota.tribunnews.com/2018/08/24/rumah-kreatif-di-tanjung-priok-jadisarana-mantan-pengguna-narkoba

Jack, R. (1995). Empowerment in Community Care. UK: Chapman \& Hall.

Media Keuangan. (2018). Melindungi Negara dari Narkoba. Diperoleh 10 Agustus 2019 dari https://www.kemenkeu.go.id/media/9746/media-keuangan-april2.pdf

Nikkhah, H.A., Redzuan, M. (2009). Participation as a Medium of Empowerment in Community Development. European Journal of Social Sciences Vol 11 no 1. Diperoleh 10 Agustus dari https://www.researchgate.net/profile/Hedayat_Nikkhah/publication/281604206_Part icipation_as_a_medium_of_empowerment_in_community_development/links/56a77 22508aeded22e36d333.pdf

Nopitasari, D., Rostyaningsih, D. (2017). Implementasi Program Pemberdayaan Alternatif Masyarakat Perkotaan Pada Kawasan Rentan Narkoba di Kampung Pertanian Jakarta $\begin{array}{lllll}\text { Timur. } & \text { Diperoleh } & 10 & \text { Agustus } & 2019\end{array}$ http://journal.student.uny.ac.id/ojs/index.php/pls/article/download/8183/7778

Prakoso, R. (2017, April 29). Pertamina-Yayasan Kumala Berdayakan Anak Jalanan. Diperoleh 18 Agustus 2019 dari https://www.beritasatu.com/investor/427842/pertaminayayasan-kumalaberdayakan-anak-jalanan 
Pratomo, Y. (2019, Mei 16). APJII: Jumlah Pengguna Internet di Indonesia Tembus 171 Juta Jiwa. Diperoleh $18 \quad$ Agustus 2019 dari https://tekno.kompas.com/read/2019/05/16/03260037/apjii-jumlah-penggunainternet-di-indonesia-tembus-171-juta-jiwa

Ristianto, C. (2019, Juni 26). BNN Sebut Jumlah Penyalahgunaan dan Peredaran Narkotika Semakin Meningkat. Diperoleh $10 \quad$ Agustus dari https://nasional.kompas.com/read/2019/06/26/11421691/bnn-sebutpenyalahgunaan-dan-peredaran-narkotika-semakin-meningkat

Situmeang, I. V. (2016). Corporate Social Responsibility: Dipandang dari Perspektif Komunikasi Organisasi. Yogyakarta, Indonesia: Ekuilibria

Undang-undang Nomor 6 Tahun 2014 tentang Desa pasal 1 ayat 12

We Are Social (2019). Berapa Pengguna Media Sosial Indonesia?. Diperoleh 18 Agustus 2019 dari https://databoks.katadata.co.id/datapublish/2019/02/08/berapa-penggunamedia-sosial-indonesia 